\title{
PUBLIC HEALTH.
}

\author{
By SIR CUTHBERT SPRAWSON, C.I.E., M.D., F.R.C.P.
}

In considering the public health of any foreign State one must compare its general conditions and its standards with those of some country that one knows, if possible a country with similar conditions. Such a comparison should involve a computation of the figures of the vital statistics of the foreign country, especially those of the morbidity or mortality rates of the more important infectious diseases. In addition, a knowledge of the size, population and conditions that will influence such statistics is essential in order to make a comparison more intelligible. The following few facts about the U.S.S.R. should therefore first be realized.

(a) The area of the U.S.S.R. is vast, being about one-sixth of the inhabited land surface of this planet.

(b) The census of January, I939, showed the population to be I70.5 million. If the new Republics, such as Bessarabia and the Baltic States, since added, were to be included, the total population may be taken to be I93 million. Asiatic Russia covers an area four times as large as European Russia ; but three-quarters of the total population live on the European side. The population is increasing rapidly, especially the urban and industrial elements. The U.S.S.R. claim that their population has the most rapid rate of increase in the world, being I.23 per cent. annually: this would give an added number of over $2 \frac{1}{4}$ million a year. So recently as 1926 only 17.9 per cent. of the population were urban : by January, I939, 32.8 per cent. or 56 million people were living in cities.

(c) There is a great diversity of nationality. In some cases nations have mixed, but in others they still remain distinct. The U.S.S.R. estimate them at 50 nations and about 200 smaller nationalities : about $5^{8}$ per cent. of the total population may be termed Russians. There are numerous different languages.

(d) The climate is similarly diverse. Many areas are subject to extremes of heat and cold, and seasonal rainfalls; but some of the Central Asian areas are dry.

(e) In instituting their public health measures the Soviet Government started almost from scratch. Before I9I4 there were hospitals and doctors, but of preventive medicine there was very little, practically nothing in rural areas. Even vaccination against small-pox was most imperfect. Then came the Great War, civil war, and severe epidemics of typhus fever and famine. The start of true progress may be dated from 1922 ; while from I928 the more rapid progress under the five-year planning system began.

To understand completely the organization of public health in the U.S.S.R. it would be necessary to know something of the social and political organization of that State; but the main principles can be given here. The Public Health Commissariat of the State undertakes everything both in curative and preventive medicine that is connected with the health of the citizen from before his birth till his death, even to such details as the manufacture of all drugs and surgical instruments. The main principle throughout is the prevention of disease. .Under the constitution citizens have the right to free medical treatment and to maintenance in the case of loss of working capacity through illness. All medical workers are employed and paid by the State.

To combat primary causes of disease, such as abnormal living or working conditions, the working day is limited to eight hours with a compulsory annual holiday of a fortnight or a month on full pay, and child labour is prohibited. The basic unit for both preventive and curative purposes is a so-called first-aid post at factories, works, mines, etc. The doctors and nurses of these posts have a sanitary control of the surroundings and of the food in the canteens and restaurants. They examine all workers periodically and treat the less severe cases of illness or accident. If a worker becomes a hospital case he is then sent to a polyclinic, where there is a complete medical service, including specialists. A polyclinic may be for a district or several factories and its staff keep contact with the medical staff of the constituent factories. Everyone in the U.S.S.R. has a record card which gives details of medical history, diagnosis and treatment. These cards are forwarded to the polyclinic or hospital concerned, and on completion of the work, back again to the man's unit: just as the medical history sheet of a soldier in our army. 
The training of the medical staff has features of interest to us, because it possesses certain differences, particularly as regards preventive medicine, from that of other countries. Russia and India are the only countries I am aware of where the Government supports the training of two distinct grades of medical practitioners. In India the economic and social conditions of that country will probably require the survival of the lower grade for some time yet. In Russia the duality has existed since at least the eighteenth century. When the Soviet Government took charge after the Revolution there was an attempt to abolish the lower grade, but experience showed it was wiser to retain it at least for the present, and that class is now more numerous than ever. The senior grade consists of university-standard graduates, called physicians, who after ten years at school undergo a five-years' medical course. The lower grade, whom we may conveniently term medical assistants, have only seven years at school followed by three years' medical training. This latter class is intended primarily to assist the physicians; but they are very frequently in independent charge, especially in rural areas. The numbers of both classes have lately increased enormously. In 1892 there were only I2,435 physicians in Russia. In I9I4 there were about 20,000 graduate physicians and 30,000 of the assistant class. At the end of 1940 there were 120,000 graduates and a larger proportional increase in the assistants: while during I94I I7,600 more physicians are graduating and the medical assistants will increase by 66,000 . The large increase of the lower class is due partly to the opening of many medical schools in several primitive areas in Asia whose licentiates will presumably practice mainly among their own communities. An increasing proportion of the undergraduate students are women. Rather more than half the students now are women: when I saw the Leningrad First Medical Institute in I938 I was told that about 75 per cent. of the students newly admitted were women. An interesting point is that a student can specialize in hygiene or in diseases of children during his five-year course, so that he can qualify and obtain a public health diploma in that time as well. To do this a student may at the start enter either a medical college (so-called Institute) or an Institute of Hygiene. For the first three years the course is the same for all. After that time if the student elects for general medicine or for diseases of children he is probably transferred to one of the large medical institutes, though he may, if he prefer, stay on at the hygiene institute. They all receive qualifications enabling them to practise medicine, and even the hygienists receive instruction, though less than the others, in clinical medicine : but the last two years of the course have a bias towards the speciality the student has selected. To show the proportions that exercise this specializing privilege; in the whole U.S.S.R. during I938 25,000 new students entered: of this number 4,000 selected children's diseases and 3,200 public health, leaving the balance for general medicine. This early specialization, I was told, is by way of experiment and the Soviet authorities are watching the results; but it has been going on since r934.

It is impossible in the scope of this brief article to say much of the results achieved by the U.S.S.R.'s energetic campaign against disease; but progress in all directions has been surprisingly rapid. A few figures may be quoted. For example, the new State found itself faced by one of the worst typhus epidemics known, and the following show the number of typhus cases per ro,000 of population in certain years :-

$\begin{array}{llllll}\text { I9I3 } & \ldots & 7.3 & \text { I925 } & \ldots & 4.6 \\ \text { I922 } & \ldots & \text { Io9.6 (probably much underestimated) } & \text { I929 } & \ldots & 2.0\end{array}$

Since then there has been further reduction and cases are now only occasional. It is possible that the abnormal conditions of the present war may resuscitate this evil.

Smallpox was formerly common in Russia. The following figures of smallpox morbidity per I0,000 of population speak for themselves :-

$\begin{array}{llllll}\text { I9I3 } & \ldots & 4.1 & \text { I929 } & \ldots & 0.37 \\ \text { I922 } & \ldots & 4.7 & \text { I935 } & \ldots & 0.2 \\ \text { I925 } & \ldots & \text { I.I } & \text { I936 } & \ldots & 0.025\end{array}$

The improvement is most striking in some of the more remote parts of the U.S.S.R., and in the present year each of the Soviet Republics of Armenia, Georgia and Kirghiz reports on case of smallpox within the last five years. 
The Soviet campaign against tuberculosis is worthy of a long chapter to itself, for some of its methods are original and might be studied with a view to adoption elsewhere. With the recent great increase in industrialism and urbanisation previous experience would have led us to expect that the tuberculosis mortality rate would rise, and doubtless it would have done so but for the energetic measures taken to combat it. The figures for the tuberculosis mortality per I0,000 for the two largest cities before and since the Revolution are :-

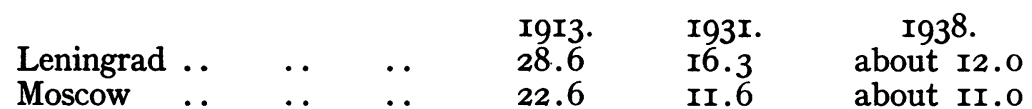

The improvement is great, but more is aimed at, and in time will be obtained. The England and Wales comparable figures for I9I3 and I938, respectively, are ro.04 and 6.3 per 10,000.

A few facts about improvement in physique since the days of the Great War may be noted.

(a) Boys of fourteen in a town near Moscow were on an average 2 inches taller and $4 \frac{1}{2}$ pounds heavier in 1934 than boys of the same town in I885. Girls were nearly 2 inches taller and four-fifths of an inch more round the chest.

(b) Comparing army recruits aged eighteen years for the years 1927 and I933 in Leningrad, there was in the latter year an increase of a quarter of an inch in height, almost $4 \frac{1}{2}$ pounds in weight and nearly one inch in chest measurement. The Moscow figures show improvements very little less than those of Leningrad and those of other towns are similar.

(c) In the last six years to I940 the weight of new-born infants in the city of Kharkov has shown an average increase of 200 grammes, while the height increased by one and a half centimetres.

(d) In Moscow during the last ten years to I940 the average height of fifteen-year-old juveniles has increased by $3 \mathrm{cms}$. and their weight by 2.5 kilos.

Lastly, in pre-revolutionary Russia the infant mortality averaged 244 per 1,000 . In an arduous campaign the U.S.S.R. have by 1936 brought this down to II8 per I,000. Still room for improvement; but it must be remembered that the infant mortality for England and Wales in I900 was I54 per I,000, brought down by I935 to 57 per I,000.

Space does not allow me to say anything of the great work done for the health of children and of mothers ; nor of the important studies in nutrition, nor of the vast amount of research in all branches of medical science that still goes on in spite of the war. One might explain also how the control of the U.S.S.R. Public Health Commissariat is devoluted to the smaller bodies; but to those that desire a fuller account I recommend Dr. Henry Sigerist's book "Socialised Medicine in the Soviet Union." 